DOI: $10.17148 /$ IARJSET.2021.8950

\title{
MOBILE BANKING: CHANGE IN CUSTOMERS ATTITUDE AND SATISFACTION IN THE ERA OF COVID-19
}

\author{
Andrea Varghese ${ }^{1}$, Dr.Umesh $\mathbf{U}^{2}$ \\ ${ }^{1}$ Research Scholar ,Department of Commerce,Panampilly Memorial Government College, \\ Chalakudy ,Thrissur \\ ${ }^{2}$ Assistant Professor and Research supervisor ,Department of Commerce, \\ Amal College of Advanced Studies,Nilambur
}

\begin{abstract}
Mobile banking is an application of mobile accessing which offers the customers with the support required to be able to bank anywhere, anytime using a mobile handheld gadget and a mobile facility such as short message service(SMS).Mobile banking provides services like balance inquiry, credit transfer and sharing other informations.Informations is send through the mobile phone. Mobile banking is safe and secure because banking transactions are encrypted and password-protected.

The concept of customer satisfaction has become more important. Banks are promoting mobile banking system to improve their operations and to reduce cost during the pandemic period. There for ,there is a need to understand the overall satisfaction of customers towards mobile banking. This issue is important because the answer holds the clue that will help the banking industry to formulate their marketing strategies to promote new dimension in customer satisfaction of mobile banking system in the future. So this research is designed to examine the overall satisfaction of customers towards mobile banking during Covid -19 .
\end{abstract}

Keywords: Mobile Banking ,Covid-19, customer attitude, customer satisfaction

\section{INTRODUCTION}

Customer satisfaction is a measure on how the services provided or supplied by an organization meets or exceeds the expectations of a consumer. Customer satisfaction is obtained through meeting the expectations that consumers have about the mobile banking service, if the expectations of the reliability, safety, ease of use ,etc. is met by the service, customer satisfaction will be high and if not, it will be low.

Mobile banking is an application of mobile accessing which offers the customers with the support required to be able to bank anywhere, anytime using a mobile handheld gadget and a mobile facility such as short message service(SMS).Mobile banking provides services like balance inquiry ,credit transfer and sharing other informations .Informations is send through the mobile phone. Mobile banking is safe and secure because banking transactions are encrypted and password-protected.

The concept of customer satisfaction has become more important. Banks are promoting mobile banking system to improve their operations and to reduce cost during the pandemic period. There for there is a need to understand the overall satisfaction of customers towards mobile banking. This issue is important because the answer holds the clue that will help the banking industry to formulate their marketing strategies to promote new dimension in customer satisfaction of mobile banking system in the future. So this research is designed to examine the overall satisfaction of customers towards mobile banking during lockdown period.

\section{STATEMENT OF THE PROBLEM}

Covid-19 pandemic posed a great challenge for the banking sector to an increase in mobile banking services which become a new normal and necessity for users of financial/banking services. The study seeks empirically to test the impact of mobile banking quality services from the view point of customers satisfaction during lockdown period .In the present serious condition ,customers are progressively mindful of observing gaps among banks corresponding to their e-service quality and how utilizing proficient innovations and updating its status intermittently when required .This study has 


\section{International Advanced Research Journal in Science, Engineering and Technology}

Vol. 8, Issue 9, September 2021

DOI: $10.17148 /$ IARJSET.2021.8950

tended to focus mainly on overall customer satisfaction and factors which impact attitudes towards mobile banking adoption during lockdown period.

\section{OBJECTIVES OF THE STUDY}

1.To determine the overall satisfaction towards mobile banking during lockdown period.

2. Customer attitude and satisfaction towards mobile banking during lockdown period.

3.To determine the customer mobile banking behaviour during lockdown period.

\section{SCOPE OF THE STUDY}

The study helps in knowing how far the mobile banking services are used by the customers. The study further extends and helps to develop an increasing association with the customers through mobile banking services .During the pandemic period Covid- 19 the customers have increased using online banking services, hence mobile banking holds a major role. Mobile banking services has increased to a wide range during lock down period due to its ease of operation .Mobile banking has opened the doors for all the customers, to operate beyond boundaries. Future research can be done in analyzing the competitive performance of mobile banking services provided by private sector as well as public sector banks. The study has been done on the usage of these services by the customers, in order to measure the satisfaction of customers towards mobile banking during lock down period.

\section{RESEARCH METHODOLOGY}

Descriptive research design is followed for conducting the study . Both primary and secondary sources have been used for study. Primary data has been collected using questionnaire. Secondary data has been collected from books ,journals ,reports ,websites and newspapers. Population of study comprised the resident of Irinjalakuda using mobile banking services between the age of 20 and 70. Individuals who have been using mobile banking services since last 12 months were targeted for the study. Convenience Sampling method was used. The sample size was 100.

\section{LITERATURE REVIEW}

1.Chandran, R. (2014)in his article “ Pros and cons of Mobile banking. International Journal of Scientific and Research Publications "he says that Over the years, banking has transcended from a traditional brick-and mortar model of customers queuing for services in the banks to modern day banking where banks can be reached at any point for their services.

2.Thakur, R.(2014). What keeps mobile banking customers loyal? “International Journal of Bank Marketing “.Ease of use or usability is one of the most important factors for determining the quality of a web site and therefore, it influences the levels of customer satisfaction.

3.Amola bhatt, S. B.(2016)in his article "Factors Affecting Customer's Adoption of Mobile Banking Services. Journal of Internet Banking and Commerce" he says demographic, attitudinal, and behavioural characteristics of mobile bank users were examined. The infrastructural facility of updated user friendly technology and its availability was found to be the most important factor that motivated consumers' attitudes.

4.Chuchuen, C. (2016)in his article "The Perception of Mobile Banking Adoption: The Study of Behavioral, Security, and Trust in Thailand. International Journal of Social Science and Humanity" he says there are many factors that relate in M-banking adoption process. 
International Advanced Research Journal in Science, Engineering and Technology

Vol. 8, Issue 9, September 2021

DOI: $10.17148 / I A R J S E T .2021 .8950$

\section{DATA ANALYSIS AND INTERPRETATIONS}

Figure 1 Figure showing customers response towards safety and security of mobile transactions

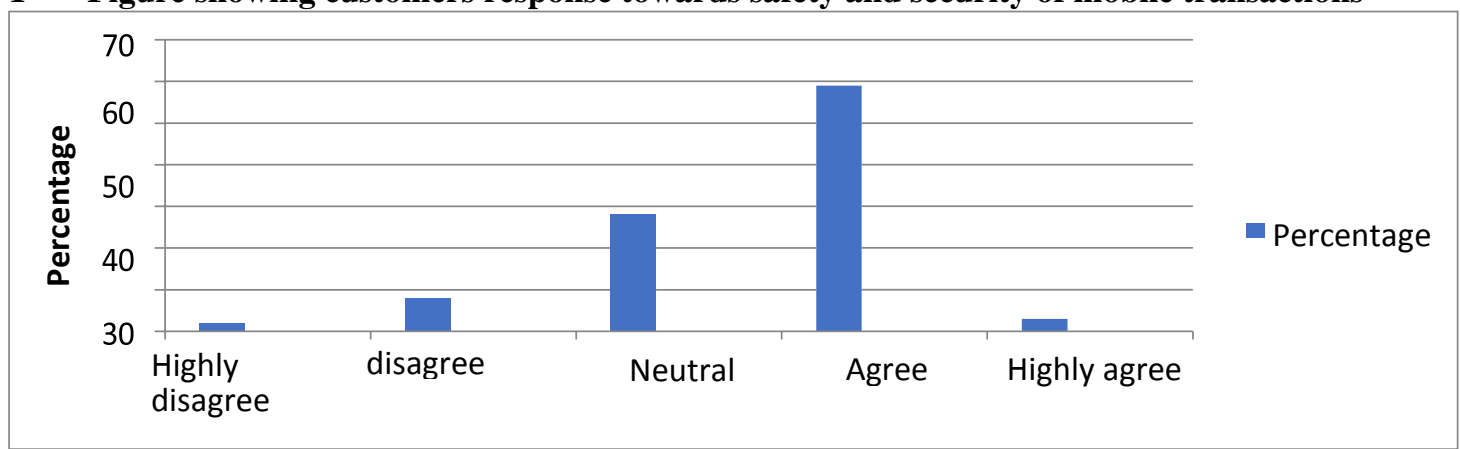

Interpretation:From the above figure it is clear that 59 percentage of customers agrees with the safety and security in making mobile banking transactions and 2 percentage of customers highly disagree with the safety and security in making mobile banking transactions.

Figure 2 Figure showing customers response towards refund facility provided for false transactions

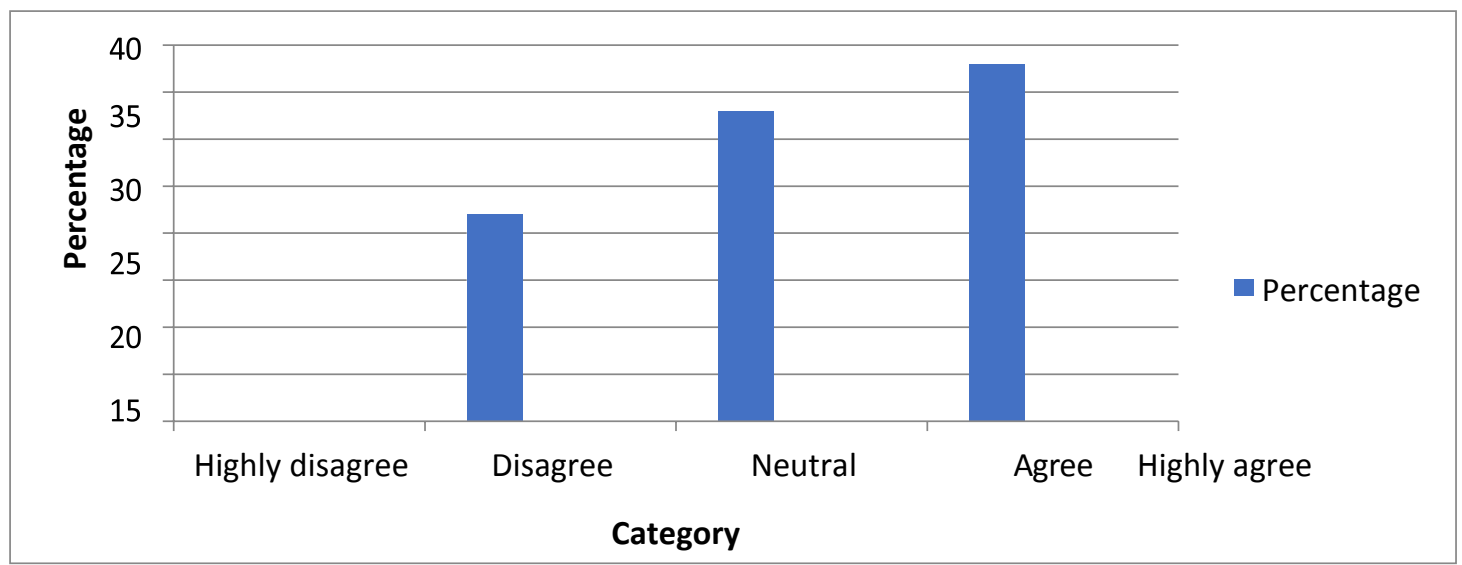

Interpretation:From the above figure it is clear that 38 percentage of customers agrees on refund facility and 22 percentage of customers disagree with the refund facility provided by mobile banking.

Figure 3 Figure showing customers responses on less degree of risk in usage of mobile banking

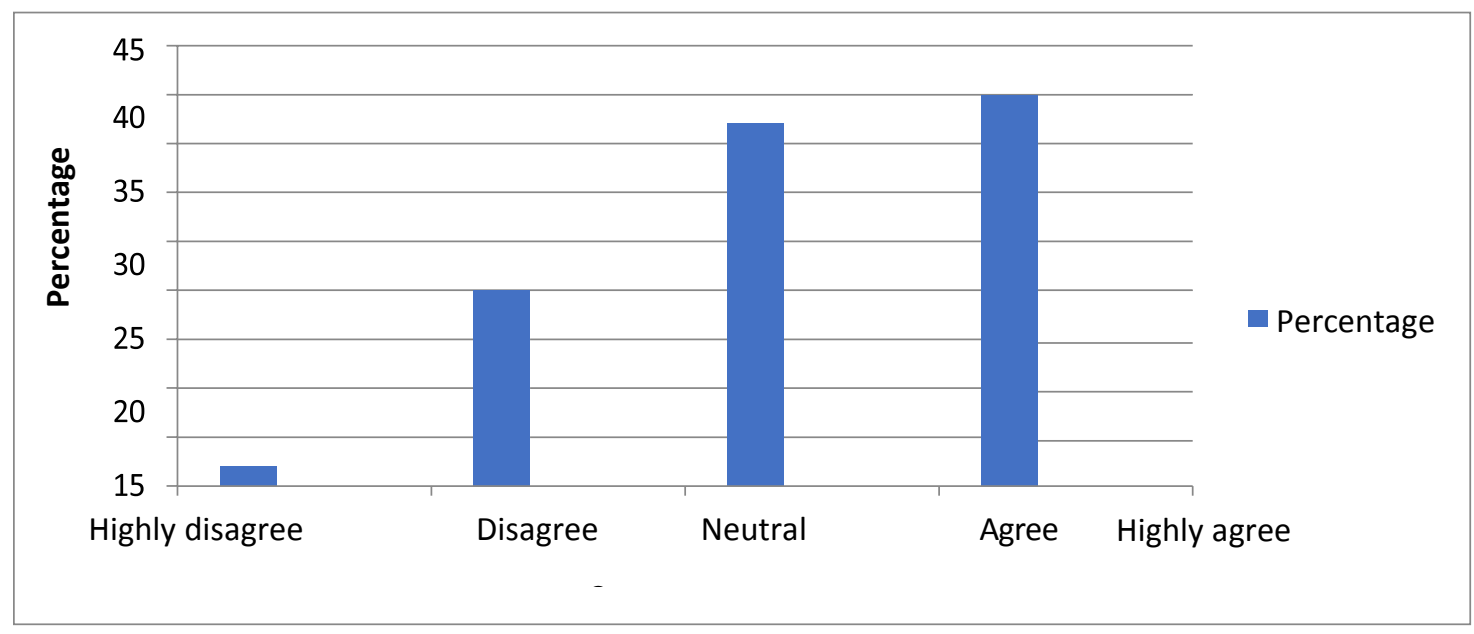




\section{DOI: 10.17148/IARJSET.2021.8950}

Interpretation:From the above figure it is clear that 41 percentage of the customers agrees that there is less degree of risk in usage of mobile banking. 2 percentage of customers highly disagree that there is less degree of risk.

Figure 4 Figure showing customers opinion on mobile banking is time saving than conventional banking

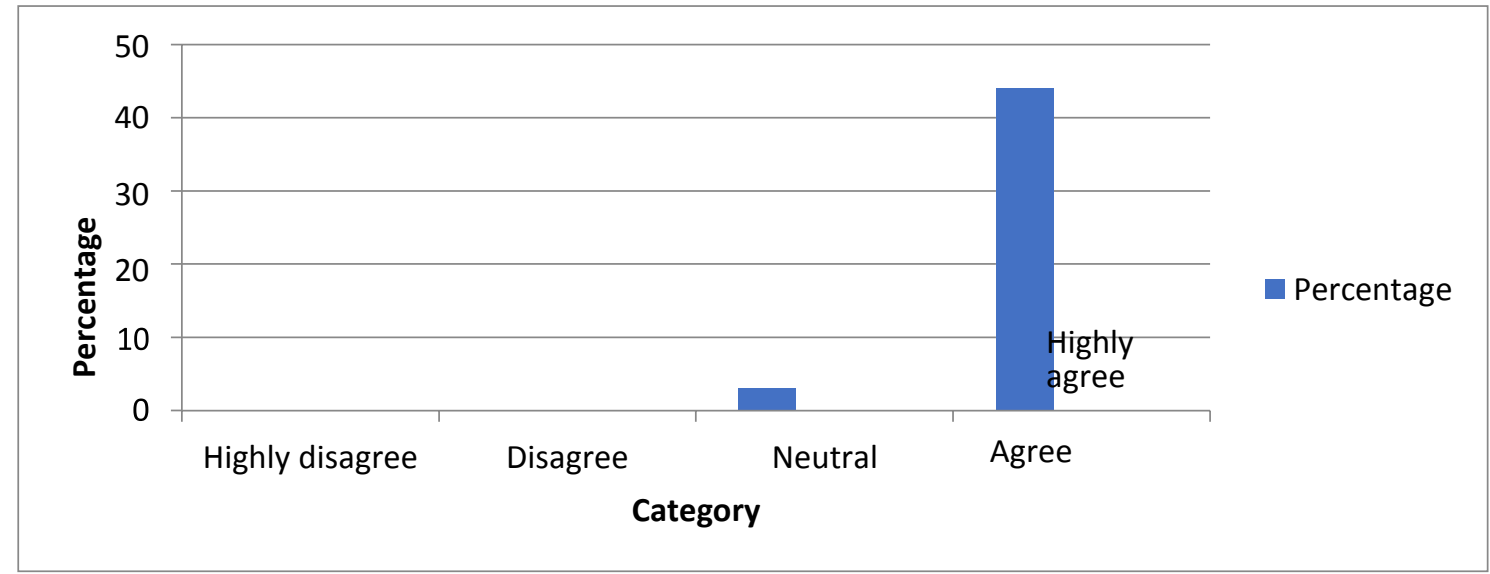

Interpretation:From the above figure it is clear that 53 percentage of the customers highly agree that mobile banking is time saving than conventional banking and 3 percentage of customers have a neutral opinion.

Figure 5 Figure showing factors that motivates customers to adopt and use mobile banking

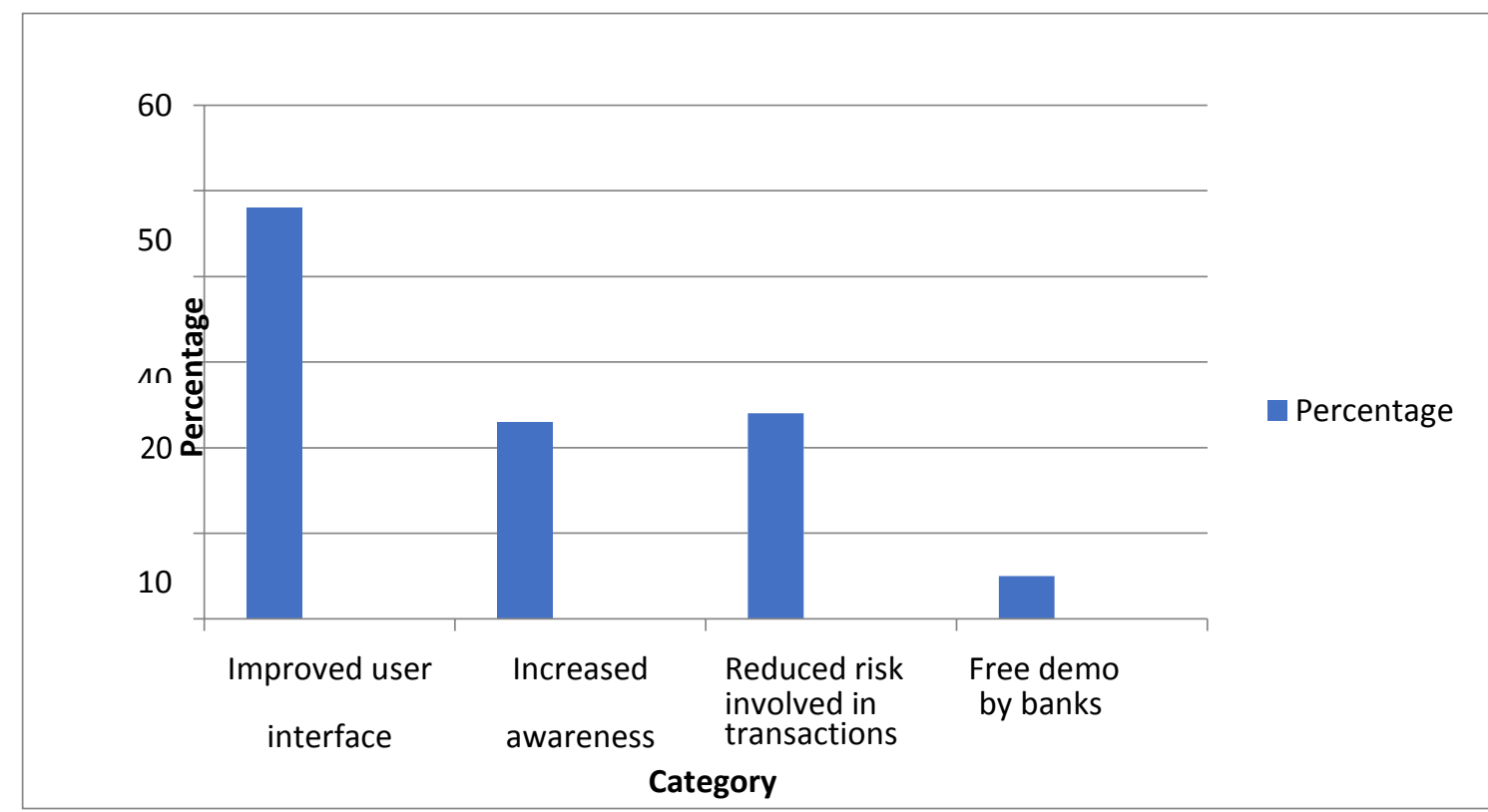

Interpretation: From the above figure it is clear that 48 percentage of customers opines that improved user interface is the factor which motivates them to adopt and use mobile banking and 5 percentage of customers opines that free demo by banks is the factor which motivates them to use mobile banking. 
International Advanced Research Journal in Science, Engineering and Technology

Vol. 8, Issue 9, September 2021

DOI: $10.17148 / I A R J S E T .2021 .8950$

Figure 6 showing overall customers satisfaction in using mobile banking

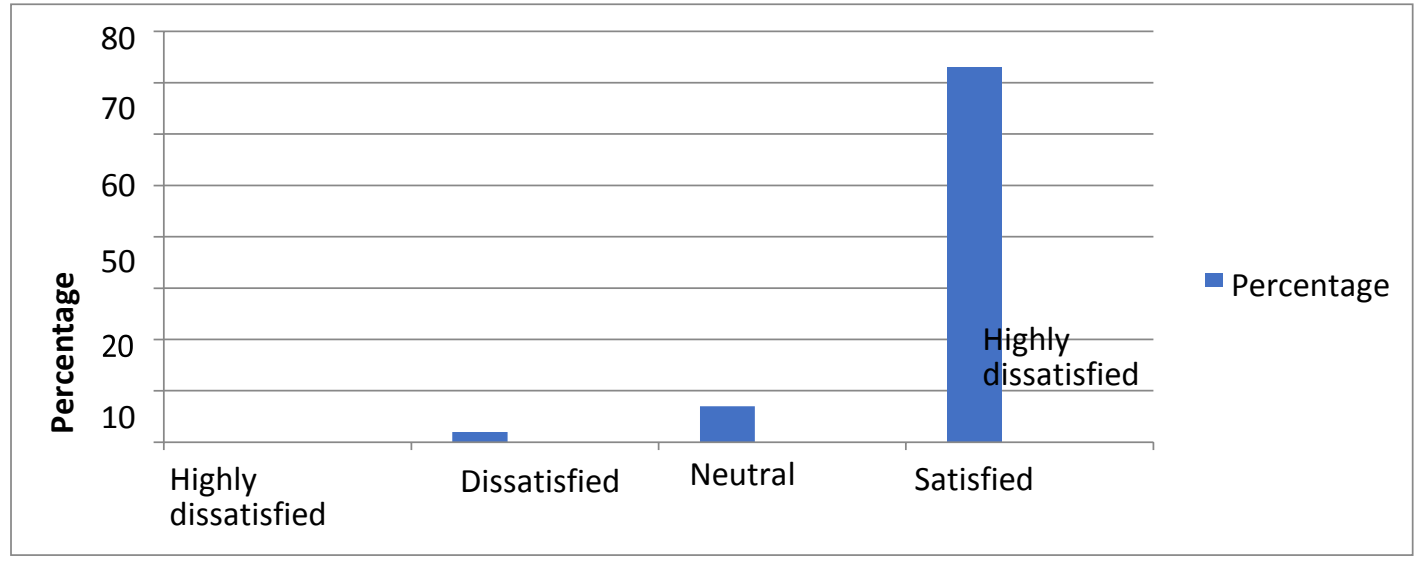

Interpretation:From the above figure it is clear that 73 percentage of customers are satisfied in using mobile banking and 2 percentage of customers are dissatisfied in using mobile banking.

Figure $7 \quad$ Figure showing frequency of using mobile banking during lockdown

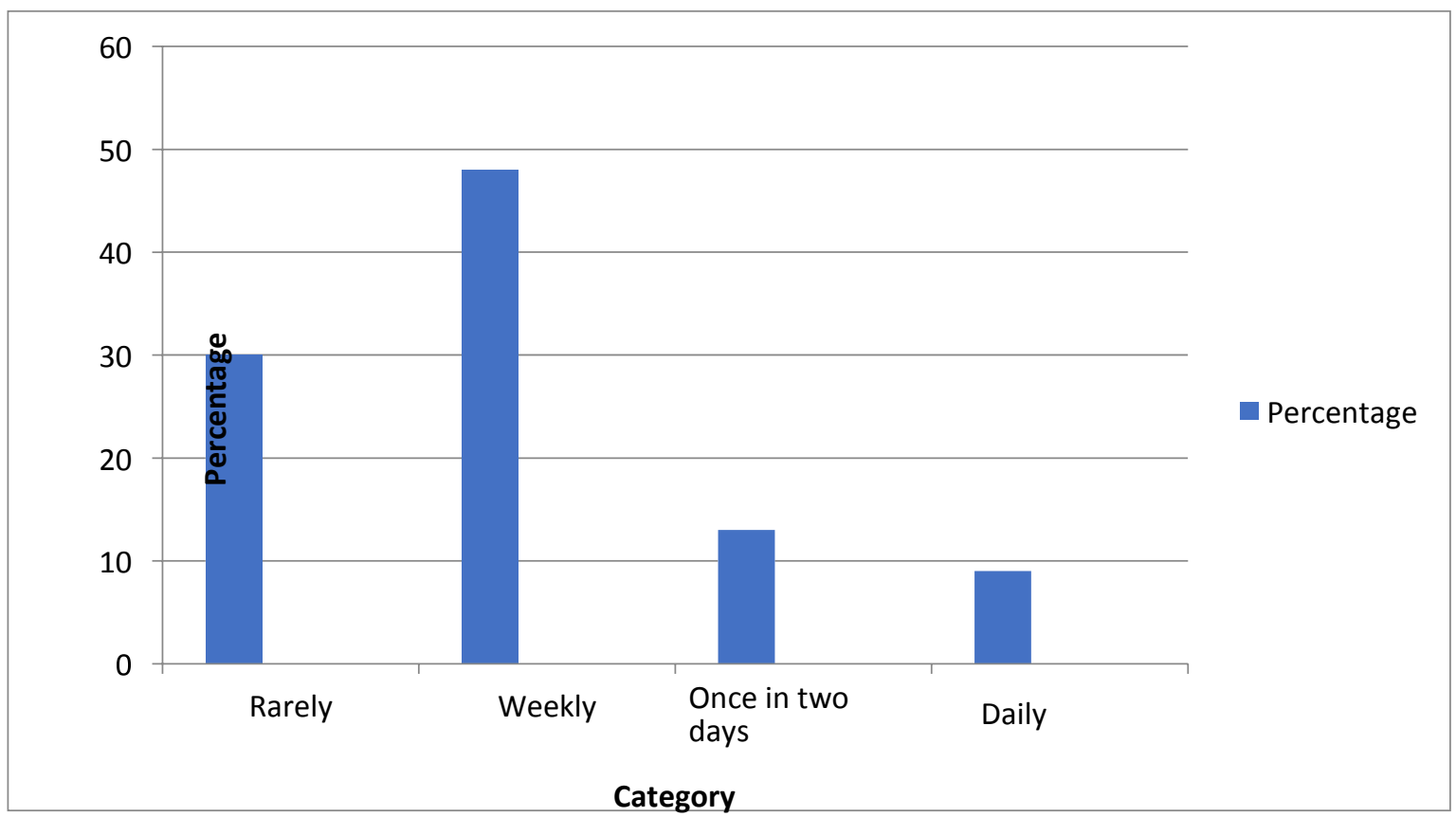

Interpretation: From the above figure it is clear that 48 percentage of the customers use mobile banking weekly and 9 percentage of the customers use mobile banking daily. 
International Advanced Research Journal in Science, Engineering and Technology

Vol. 8, Issue 9, September 2021

DOI: $10.17148 /$ IARJSET.2021.8950

Figure 8 showing customers simplicity to handle mobile banking

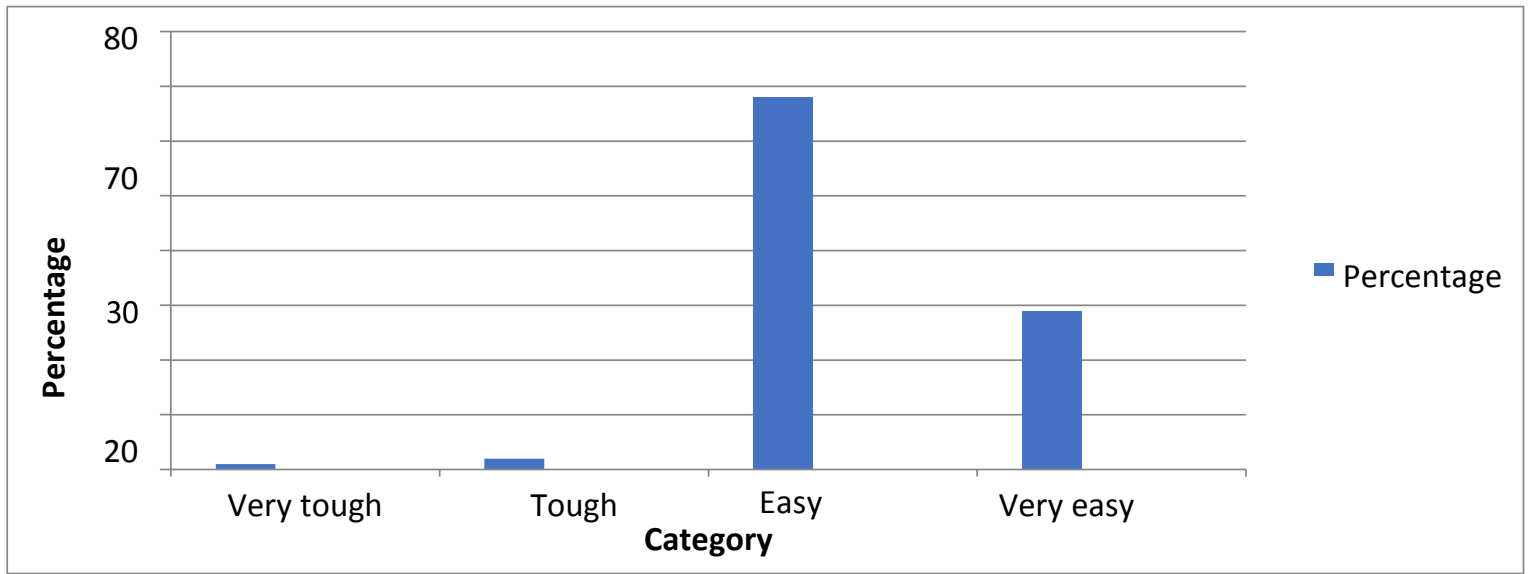

Interpretation:From the figure it is clear that 68 percentage of customers opines that it is easy to handle mobile banking and 1 percentage of the customers opines is that it is very tough to handle mobile banking.

Figure 9 showing various mobile banking apps used by customers during the lockdown period

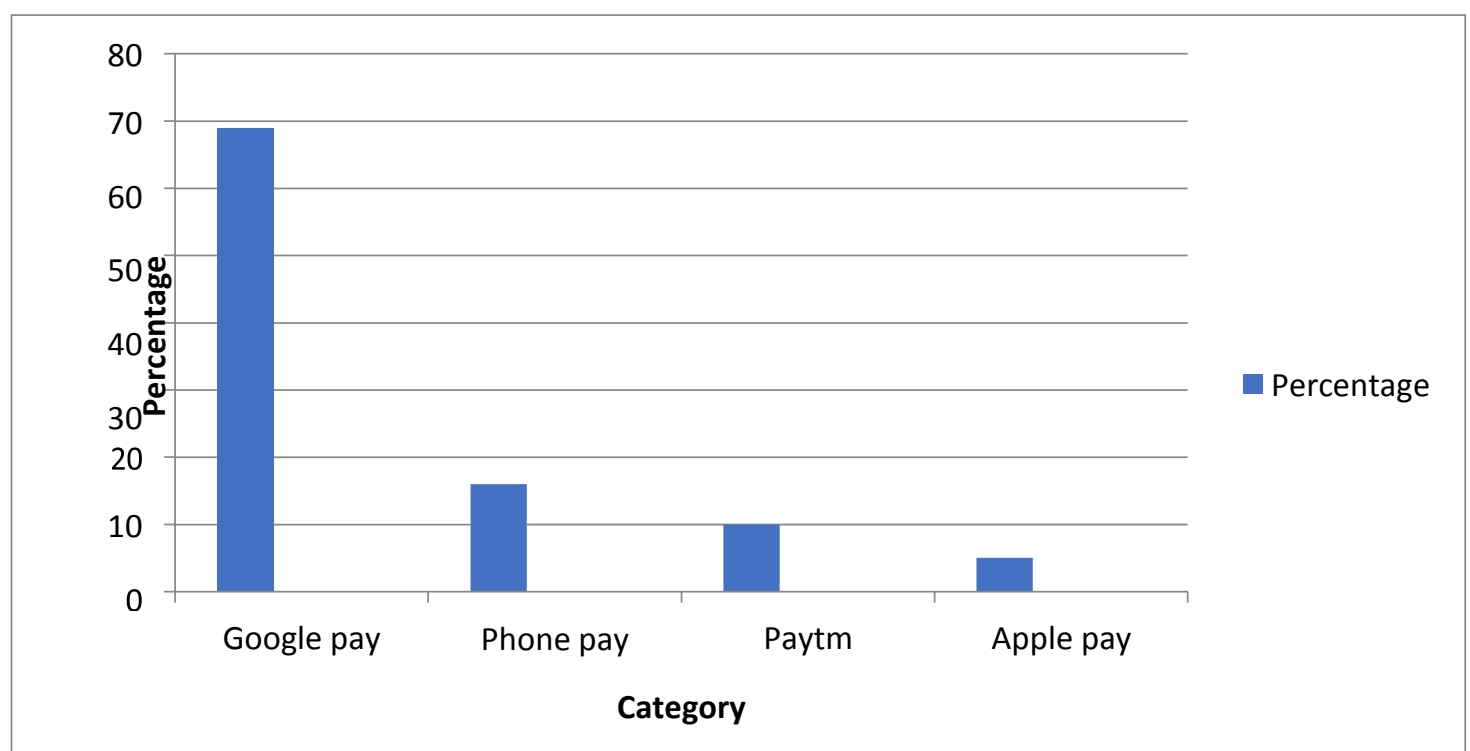

Interpretation:From the above figure it is clear that 69 percentage of customers use google pay app for mobile banking during lockdown period and only 5 percentage use apple pay app for mobile banking during lockdown period. 
International Advanced Research Journal in Science, Engineering and Technology

Vol. 8, Issue 9, September 2021

DOI: $10.17148 / I A R J S E T .2021 .8950$

Figure 10 Figure showing type of payment made by customers using mobile banking

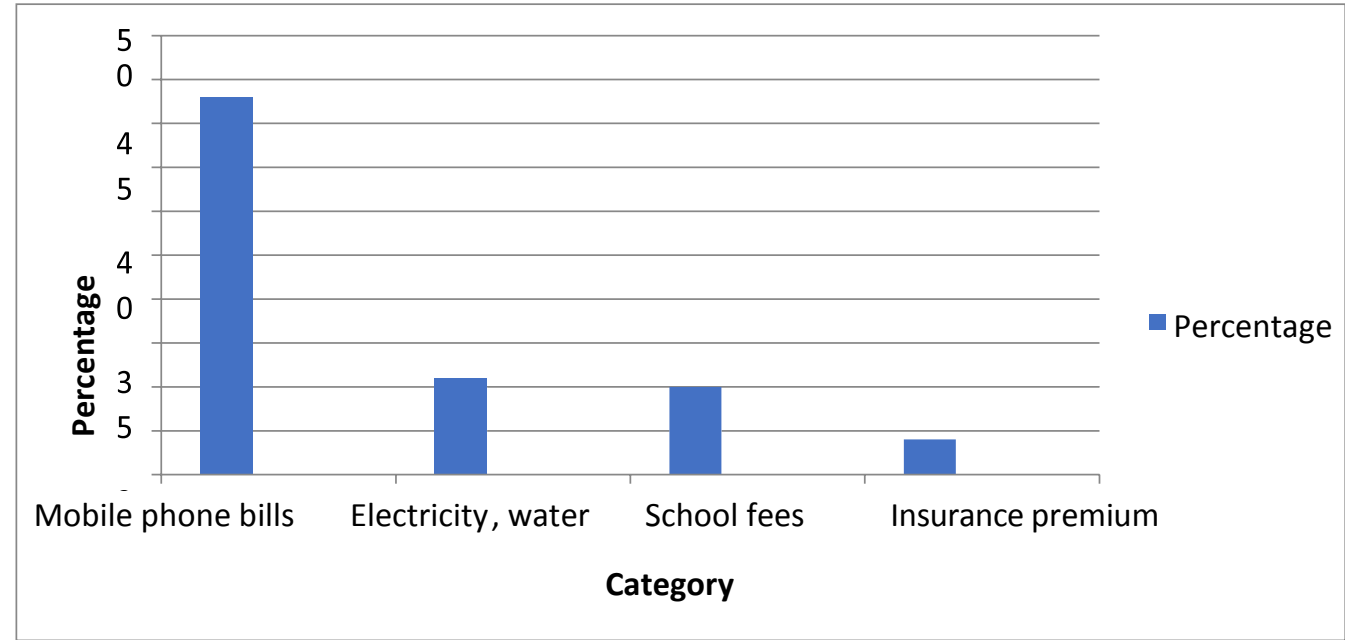

Interpretation :From the above figure it is clear that 43 percentage of customers use mobile banking for mobile phone bills payment and only 4 percentage use mobile banking for payment of insurance premium.

Figure 11 Figure showing customer response towards the factors that influenced to use mobile banking during lockdown

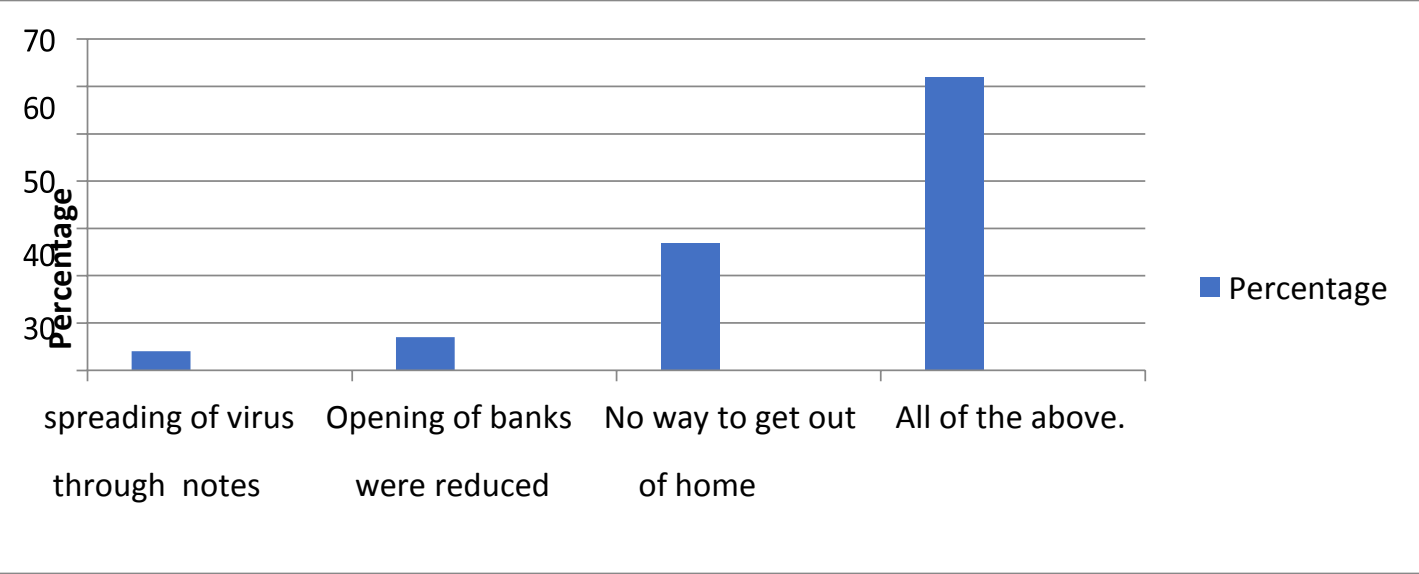

Interpretation:From the above figure it is clear that 62 percentage of customers were influenced by all factors like fear of spreading virus through currency note,opening of banks,stores, outlets were reduced,no way to get out of home while 4 percentage of customers were influenced by the fear of spreading the virus through currency notes

Figure 12 Figure showing customer response towards the purpose for which they use mobile banking

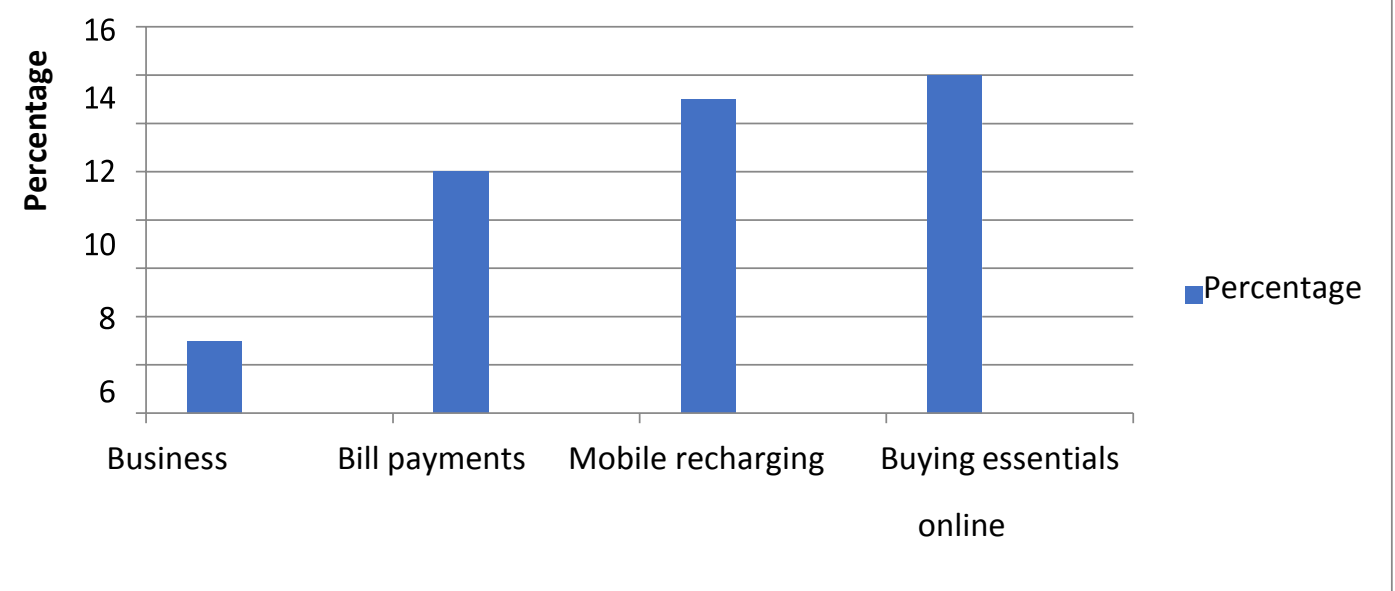




\section{International Advanced Research Journal in Science, Engineering and Technology}

Vol. 8, Issue 9, September 2021

DOI: $10.17148 /$ IARJSET.2021.8950

Interpretation:From the above figure it is clear that 60 percentage of customers uses mobile banking for all purposes like business, bill payments,mobile recharging, buying essentials online and only 3 percentage of customers use mobile banking for business purposes.

Figure 13 Figure showing customer response towards the features of mobile banking that influenced to use

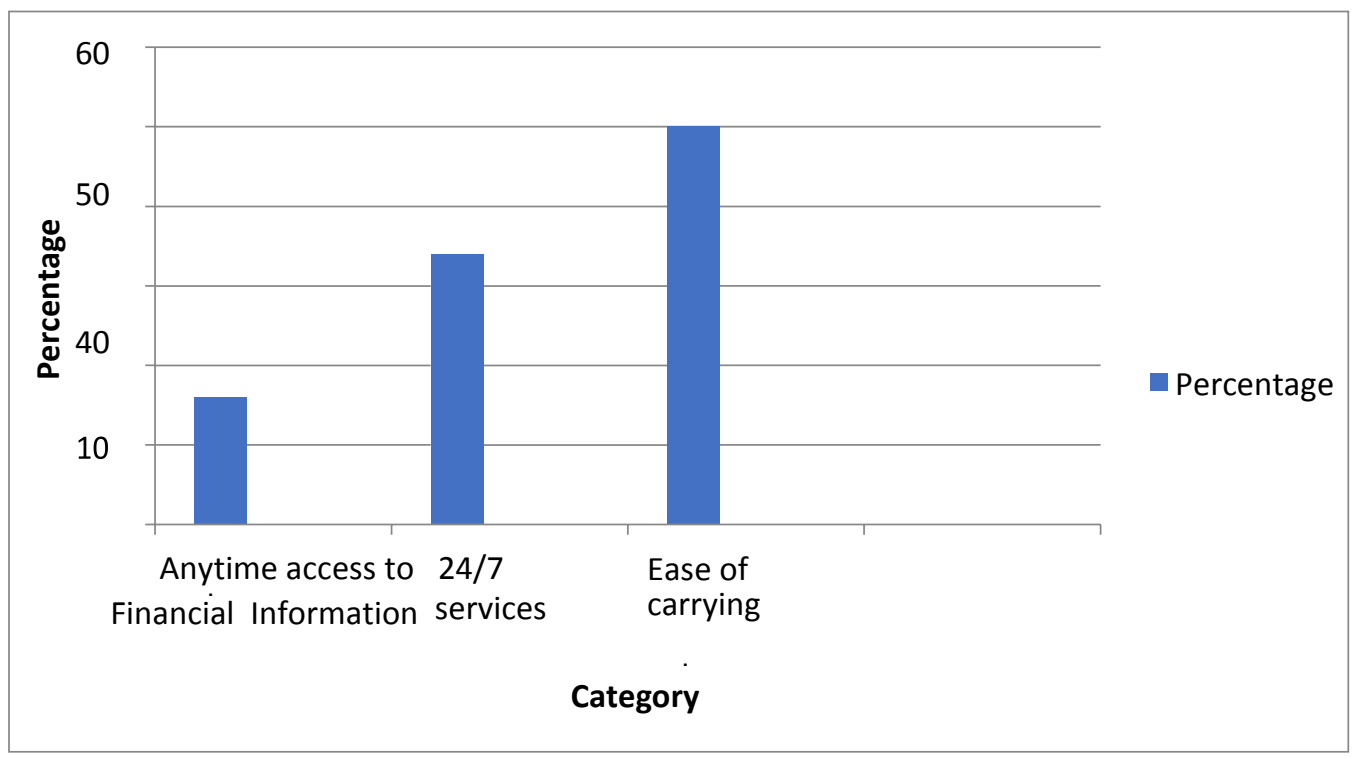

Interpretation:From the above figure it is clear that 50 percentage of customers use mobile banking because of ease of carrying out transaction and only 16 percentage of customers use mobile banking because of anytime access to financial information.

\section{FINDINGS}

1.More than half of the customers agrees with the safety security provided by mobile banking.

2.Least of the customers highly agrees that mobile banking provides refund facility on false transactions.

3.Less than half of the customers agrees with the less degree of risk involved in using mobile banking.

4.Majority of the customers are opines that mobile banking is time saving than conventional banking.

5.More than half of the customers are motivated to adopt and use mobile banking due to improved user interference.

6.Majority of the customers are satisfied in using mobile banking.

7.Almost half of the customers uses mobile banking services weekly during lockdown period.

8.Majority of the customers opines that it is easy to handle mobile banking.

9.More than half of the customers are bothered about the security issues while using mobile banking.

10.Most of the customers uses Google Pay app during lockdown period.

11.All most half of the customers use mobile banking services to pay mobile phone bills.

12.More than half of the customers are influenced by all the factors like fear of spreading virus through currency notes, opening of banks, stores, outlets, were reduced,no way to get out of home in using mobile banking during lockdown period.

13.Majority of the customers uses mobile banking services for all purposes like business, bill payments, mobile recharging, buying essentials online/online shopping.

14.Half of the customers are influenced by the ease of carrying out transactions. 
DOI: $10.17148 /$ IARJSET.2021.8950

\section{CONCLUSION}

The research shows that the satisfaction of mobile banking services of the respondents has raised during the pandemic in comparison with period before the pandemic. There is no doubt that mobile apps and online platforms have made the banking processes convenient for people. However, there is also a larger risk of hackers compromising the data resulting in huge chaos situation .So the key is to implement their online security measures with utmost care.

Bank managers should take into consideration the following post covid-19 pandemic stage to closely monitor the needs and perception of customers Because it is very possible that a large amount of them will continue to use this new interface despite the recovering of the bank's fully functionally with traditional banking. Another direction that banks should follow refers to credit products. In the conditions of majority uncertainty generated by the covid-19 crisis ,it is desirable that banks meet customers requirements and demonstrate flexibility in negotiating leading and refinancing conditions. From the study it is clear that customers are having a changing attitude towards mobile banking. The people has changed their outlook that they have towards mobile banking.

\section{REFERENCES}

1. Chandran R. (2014). Pros and cons of Mobile banking. International Journal of Scientific and Research Publications , 4 (10),pg.1-5.

2. Thakur R.( 2014). What keeps mobile banking customers loyal? International Journal of Bank Marketing 32(Iss 7):pg. 628-646.

3. Amolabhatt S.B(2016).Factors Affecting Customer's Adoption of Mobile Banking Services. Journal of Internet Banking and Commerce , $21(1), p g .1-2$

4. Chuchuen C. (2016). The Perception of Mobile Banking Adoption: The Study of Behavioral, Security, and Trust in Thailand. International Journal of Social Science and Humanity , 6 (7), pg.547-550.

5. A Qualitative Study on Impact of Covid-19 on Mobile Banking Services with Special Reference to the State of Goa". International Research Journal on Advanced Science Hub, 2, 7, 2020, 109-115. doi: 10.47392/irjash.2020.73 